\title{
Hazır Giyim Mağazacılık Sektöründe İş Kazaları ve Çözüm Önerileri: Örnek Bir Uygulama
}

\author{
Hande Ergin ${ }^{1,2}$, Ayhan Mergen ${ }^{1}$ \\ ${ }^{1}$ Marmara Üniversitesi, Fen Bilimleri Enstitüsü, İş Güvenliği Anabilim Dall, Göztepe Kampüsü, 34722 Göztepe, İstanbul \\ ${ }^{2}$ Biruni Üniversitesi, Sağllk Hizmetleri Meslek Yüksekokulu, İşSağlı̆g ve Güvenliği Bölümü, 34104 Topkapı, İstanbul
}

ÖZ

Hazır giyim mağazacılık sektörü, ülkelerin ekonomik kalkınma sürecinde etkin rol oynayan bir sanayi dalıdır. Bu sektör dünya ekonomisinde olduğu gibi ülkemiz ekonomisinde de önemli bir yere sahiptir. 76 milyondan fazla nüfusu olan Türkiye'de ekonomik gelişmeler doğrultusunda son tüketiciye yönelik hazır giyim ürünlerinin iç pazarı ve mağazacılık sektörü büyüme eğilimindedir. Gelişen teknoloji ve pazar payının büyümesi ile beraber istihdamda artış yaşanmakta ve çalışanların karşılaştığı iş kazaların sayısı da artmaktadır. Dünyada bütün gelişmiş ülkelerde olduğu gibi ülkemizde de en önemli kavramlardan biri iş sağlığı ve güvenliğidir. Bu çalışmada hazır giyim mağazacılık sektöründe yaşanan iş kazaları örnek bir firma üzerinden ki-kare istatistik yöntemi kullanılarak, SPSS istatistik programı yardımı ile araştırılmış ve çözüm önerileri sunulmuştur.

Anahtar Kelimeler: İş Kazası, İş Güvenliği, Hazır Giyim, Mağazacılık, SPSS

\section{Occupational Accidents and the Solutions in the Apparel Retail Sector: A Sample Application}

\begin{abstract}
Sector of retail apparel that plays an effective role in the economic development process of the country, is a part of industry. This sector has an important place in our country's economy, as well as world. More than 76 million population of Turkey's retail sector tends to grow in line with the economic developments for apparel products to the final consumer. With developing technology and market share with growth being experienced an increase in employment and the number of occupational accidents encountered by workers is also increasing. One of the most important concepts in our country as well as in all developed countries in the world is the occupational health and safety. In this study, samples of work accidents that occurred in the retail apparel sector has been investigated with using ki-kare statistical method and the help of SPSS program and has been presented solutions.
\end{abstract}

Keywords: Work Accident, Occupational Safety, Apparel, Retail, SPSS

\section{GİRİ̧̧}

Gelişen teknoloji ile beraber çalışanların karşılaştığı güvensiz durumlar artmaktadır. Güvensiz durumların yanı sıra çalışanlar tempoya ayak uydurmaya çalışmakta ve bu durum fizyolojik, psikolojik baskılar oluşturmaktadır. Bu tür olumsuzluklar çalışanların güvensiz davranış sergilemelerine yol açmaktadır. Gerek güvensiz davranışlar, gerek çalışanların karşılaştığ1 güvensiz durumlar iş verimini de etkilemekte ve bütün bunlardan dolayı da sağlık ve güvenlikle ilgili alınan tedbirlerin önemi daha da artmaktadır.
Yapılan araştırmalara göre Türkiye'de sekiz dakikada bir iş kazası yaşanmakta, altı saatte bir ölümlü iş kazası ve iki buçuk saatte bir sakat kalma ile sonuçlanan iş kazaları yaşanmaktadır [1]. Sanayileşmenin artması ile iş kazalarının sayısı da günden güne artmaktadır. Her geçen gün iş kazalarıyla doğrudan ve dolaylı kayıpların büyük boyutlara ulaşmas1, konunun önemini daha da arttırmaktadır.

Dünyada sanayileşme artarken hazır giyim üretim ve mağazacılık sektöründeki gelişmeler de önemli bir artış göstermiştir. Sanayi Genel Müdürlüğü tarafından yapılan 
çalışmalar gösteriyor ki; tekstil, hazır giyim ve deri sektörleri 2013 yılı içerisinde 29 milyar dolar ihracat yapmıştır. Bu rakamların 2023 yılında 80 milyar dolara kadar yükselmesi planlanmıştır. Bunun yanı sıra ülkemiz, 2013 yılı içerisinde dünya hazır giyim ihracatının \%3.7 lik kısmını oluşturmaktadır. İmalat sanayi sektörleri incelendiğinde 2013 y1lı içerisinde "net ihracatçı" sıralamasında ülkemiz birinci sıradadır [2]. Onuncu Kalkınma Planı'nda planlanan hedefler doğrultusunda, Türkiye'nin ihracattaki \%35'lik pay1, istihdamın tek başına \%11'ini ve GSMH'nin \%10'unu karşılaması ve sanayideki yatırımların $\% 25$ 'ini bünyesinde toplaması tekstil ve hazır giyim sektörünün ülke ekonomisinin en önemli kollarından biri olduğunu göstermektedir [3].

\section{1 İs Sağllğı ve Güvenliği Kavramları}

İş sağlı̆̆ 1 ve güvenliği; iş yerlerinde işin yürütülmesi sırasında, çalışanın sağlığına zarar verebilecek koşulları analiz eden ve bu olumsuz koşullardan korunmak amacıyla sistemli ve bilimsel değerlendirmeler yapan çalışmaların tamamıdır [4]. İş güvenliği çalışma ortamında sürekli olan risk ve tehlikeleri, tespit edip kaynağında önlemeyi, iş kazalarını ve acil durumları ortadan kaldırmayı amaç edinir [5].

\subsubsection{Işs Sağllğl ve Güvenliğinin Amacl ve Önemi}

İş sağlığı ve güvenliğinin öncelikli amacı çalışanları korumaktır. Çalışanları işyerinin olumsuz etkilerinden korumak, güvenli, sağlıklı ve rahat çalışma ortamı yaratmak asıl amaçlardandır. Başka bir deyimle, çalışanları meslek hastalıklarına ve iş kazalarına karşı koruyarak beden ve ruh tam iyilik hallerini sağlamaktır. İkinci önceliği ise üretim güvenliğini sağlamaktır. Üretimin güvenliğini sağlamak demek dolaylı olarak çalışanın güvenliğini sağlamak anlamına gelmektedir. Bir işletmede üretim güvenliği sağlandığ takdirde iş verimi artacaktır, bu durum ekonomik olarak işverene ve işçilere de yansıyacaktır. Üretim güvenliği olan bir işletmede çalışanların da meslek hastalığına ya da iş kazasına uğrama ihtimalleri azalmaktadır. İş sağlığı ve güvenliğinin diğer amacı ise işletme güvenliğini sağlamaktır [6].

İş kazalarından ve meslek hastalıklarından en çok etkilenen grup çalışanlardır. Ülkemizde iş hukukuna göre haftalık çalışma saatinin 45 saat olduğu düşünülürse, çalışanlar hayatlarının büyük bir kısmını işyerlerinde geçirmektedirler. Çalışma ortamının düzenli, güvenli ve sağlıklı olması çalışanların işyerindeki verimliliğini arttıracağı gibi aynı zamanda işi benimsemelerini ve işlerini daha dikkat ve özenle yapmalarını sağlar. Bu anlamda işverenlerin çalışma ortamında gerekli önlemleri alması ve çalışanlara iş sağlığı ve güvenliğinin önemini detaylı bir şekilde aktarmaları çok önemlidir. İş kazası ya da meslek hastalığı yaşadıklarında sürekli ya da geçici iş göremezlik yaşayan işçiler maddi ve manevi kayıplar yaşayacaktır. Yaşanan bu kayıp ile çalışanın yaşadığı psikolojik sorunların yanında, ücret gelirinin bir kısmını ya da tamamını belirli bir süre ya da sürekli olarak kaybedebilir. Bu durum hem çalışanı hem de ailesini zor durumda bırakacaktır [7].

Çalışanlardan birinin iş kazasına ya da meslek hastal1ğına yakalanması, çalışanlar kadar işvereni de önemli ölçüde etkilemektedir. İşyerinde iş kazası yaşandığı anda çal1şanlar manevi anlamda bir kayıp yaşadıkları için bu durum işin yürütümüne ve verimliliğine de zarar verir. İşin temposunun aksaması, verimliliğin ve üretimin düşmesi ya da yavaşlaması işveren açısından dolaylı mali kayıplardır. Meydana gelen kazanın büyüklüğü ne olursa olsun işveren ülke mevzuatına göre açılan davalarda kazazedeye ödenecek tazminatlar ve ödemelerle de ciddi bir kayıp yaşar. Kimi zaman zarar gören makina ve teçhizatların değiştirilmesi, kimi zaman da uzun süre kullanılmaması ve bu süre zarfinda bakımlarının yapılması gerekmektedir. Kaza nedeniyle makina ve teçhizatlarda meydana gelen hasarlar ve zaman kaybı da işveren için maliyet yaratmaktadır.

Kaza sonucunda iş göremezlik, sakatlık ya da ölüm gerçekleştiği takdirde, işveren kazazede yerine personel alımı yapmak zorunda kalmaktadır. Bu durumda kalifiye olan personelin kaybı ve yeni bir işçinin işe yerleştirilme süreci de işverene hem mali kayıp hem de zaman kaybı olarak yansıyacaktır. Ayrıca yaşanan iş kazaları firmalar için prestij ve müşteri kaybına da yol açmaktadır.

\subsubsection{Işs Kazası Kavramı ve Nedenleri}

5510 Sayılı Sosyal Sigortalar ve Genel Sağlık Sigortası Kanunu'nda 13. maddede iş kazası tanımı şu şekilde yapılmıştır: Sigortalının işyerinde bulunduğu sırada, işveren tarafından yürütülmekte olan iş nedeniyle sigortalı kendi adına ve hesabına bağımsız çalışıyorsa yürütmekte olduğu iş nedeniyle, bir işverene bağlı olarak çalışan sigortalının, görevli olarak işyeri dışında başka bir yere gönderilmesi nedeniyle asıl işini yapmaksızın geçen zamanlarda, emziren kadın sigortalının, iş mevzuatı gereğince çocuğuna süt vermek için ayrılan zamanlarda, sigortalıların, işverence sağlanan bir taşıtla işin yapıldığı yere gidiş gelişi sırasında, meydana gelen ve sigortalıy hemen veya sonradan bedenen ya da ruhen engelli hâle getiren olaydır [8].

İş kazalarının çok çeşitli olması sınıflandırma yapılmasını zorlaştırmaktadır. Cascio sınıflandırma yaparken kazaları güvensiz durumlar ve güvensiz davranışlar olarak 2'ye ayırır. Güvensiz davranışları, kişilerin yarattığı güvensizlikler olarak değerlendirir. Güvensiz durumları da fiziksel 
ve çevresel koşullar olarak ayrı ayrı değerlendirir. Fiziksel koşullar, çalışma ortamında kontrolleri ya da bakımları yapılmamış makinalar, uygun olmayan koruyucu takılmış ekipmanlar gibi durumlardır. Çevresel koşullar ise gürültü, aydınlatma, toz gibi sıralayabileceğimiz fiziksel risk etmenlerinin meydana getirdiği güvensiz durumlardır [9].

Günümüzde yaşanan iş kazaları incelendiğinde iş kazalarının üç temel nedeni olduğu tespit edilmiştir. Bu üç temel nedenler de güvensiz davranışlar, güvensiz durumlar ve tabiattan gelen kazalardır [10]. Güvensiz davranışlar, çalışanlar tarafından yapılan işyeri ortamında güvensizlik yaratan davranışlardır. İş kazalarının \%80'i çalışanların davranışlarından kaynaklıdır. İnsanların doğal yapısından kaynaklı olarak günlük işlerini yapabilmesi için belli bir enerji gereksinimi vardır. İş gücü ve fiziksel iş becerisinin üzerinde iş yapmaya çalışan insanlarda yorgunluk belirir ve yorgunluk en önemli güvensiz davranış örneklerindendir. Güvensiz durumlar, çalışma ortamında güvensizlik yaratan koşullardır. İş kazalarının \%18'i güvensiz durumlardan kaynaklanmaktadir [6].

Çalışma ortamındaki güvensiz durumlar irdelendiğinde; yönetimin organizasyon eksikliği, kusurlu olan makina ya da ekipmanlarının bakım ve onarımlarının yapılmaması, çalışma ortamının fiziksel olarak yeterli olmaması, sağlıksız çevre koşulları gibi konular en başta gelen güvensiz durum örneklerindendir. Güvensiz durumlar ciddi kazalara sebep olduğu gibi çalışanların performansını ve iş verimini de düşürmektedir. Tabiattan gelen kazalar ise iş kazalarının $\% 2$ 'sini oluşturmaktadır ve bu kazalar doğadan gelen deprem, sel gibi olaylar sonucu yaşanmış olup, güvensiz durum ya da davranışların sebep olmadığı kazalardır [6].

\subsection{3 İ̧s Kazalarının Sınıflandırılması}

İş kazaları sınıflandırılırken kazanın meydana gelme şekli, kaza sonucu oluşan zararın tespiti gibi konulara göre farklı sinıflandırılmaktadır [11].

Yaralanmanın ağırlığına göre yapılan sınıflandırmalarda ilkyardım sonucu çalışanın işbaşı yapabileceği, yaralanma ile sonuçlanan kazalar, sürekli iş görememezliğe sebep olan kazalar ve ölüm ile sonuçlanan kazalar gibi kriterler ile kaza sonucu kişinin yaşadığı zarar tespit edilir. Yaralanmanın cinsi de kaza sınıflandırmada kişinin vücudunda hangi bölgenin (el, kol, bacak, gövde, kafa vb.) yaralandığını tespit etmek açısından oldukça önemlidir. Yaralanmanın ağırlığı ve cinsi sinıflandırıldıktan sonra kazanın cinsi de tespit edilir. Kazanın cinsinde ise yaralanan kişide oluşan yaralanmalar (yumuşak doku zedelenmesi, sıyrık, kesik, kırık, yanma vb.) siniflandırılır.
Yaralanmanın ağırlığına göre sınıflamalar yaparken çalışanın işten kaç gün uzak kaldığı yaralanmanın boyutunu tespit edebilmek için oldukça önemlidir. Kaza sınıfı tespit edilirken majör, minör ve maddi hasarlı olmak üzere 3 sınıf altında inceleme yapılır [11]. Bu sinıflar:

Minör Kazalar: Minör kazalar, iş günü kaybı az olan, küçük hasarlı ve çoğunlukla ilk yardım gerektiren kazalardir.

Majör Kazalar: Çalışana önemli derecede zarar veren, dış tedavi gerektirebilen kazalardır.

Maddi Hasarlı Kazalar: Kaza sonucunda çalışanlarda herhangi bir yaralanma yoktur ancak çalışma ortamında maddi hasar söz konusudur.

\subsubsection{Türkiye İ̧ Kazaları Istatistiksel Verileri}

İş kazaları dünya çapında olduğu gibi Türkiye'de de çalışma hayatını etkileyen en önemli sorunlardandır. Ülkemizde iş kazaları ve meslek hastalıklarının bildirimi Sosyal Güvenlik Kurumu'na yapılmaktadır. SGK istatistiklerine göre ülkemizde 2014 yılında sigortalı olarak çalışan sayısı, 2013 yılına göre \%5 artışla 19.821.822 kişiye ulaşmıştır. SGK verilerinden sigortalı çalışanların işçi, esnaf ve memur olarak dağılımı incelendiğinde \%70'ten fazla işçi statüsünde çal1şanın SGK'lı olduğu ortaya çıkmaktadır. SGK'lı işçilerin \%61'i 50 kişinin altında istihdamı olan işyerlerinde çalışmaktadırlar [12].

SGK istatistiklerine göre 2013 yılında 191.389 iş kazası meydana gelmiştir. Bu sayı 2014 yılında 221,366'e yükselmiştir, yani iş kazası oranı $\% 15.6$ oranında artmıştır. Tablo 1.1 ' de yıllara göre Türkiye'de yaşanan iş kazalarının sayılarını ve iş kazasında ölen kişilerin sayılarını görebiliriz.

Tablo 1.1 2004-2014 Yılları arası yaşanan iş kazalarının sayıları ve iş kazasından ölenlerin sayısı [13]

$\begin{array}{ccc}\text { Yıllar } & \text { Kaza Sayısı } & \begin{array}{c}\text { İş Kazası Sonucu Ölen } \\ \text { Kişilerin Sayısı }\end{array} \\ \mathbf{2 0 0 4} & 83830 & 843 \\ \mathbf{2 0 0 5} & 73923 & 1096 \\ \mathbf{2 0 0 6} & 79027 & 1601 \\ \mathbf{2 0 0 7} & 80602 & 1044 \\ \mathbf{2 0 0 8} & 72963 & 866 \\ \mathbf{2 0 0 9} & 64316 & 1171 \\ \mathbf{2 0 1 0} & 62903 & 1444 \\ \mathbf{2 0 1 1} & 69227 & 1700 \\ \mathbf{2 0 1 2} & 74871 & 744 \\ \mathbf{2 0 1 3} & 191389 & 1360 \\ \mathbf{2 0 1 4} & 221366 & 1626\end{array}$




\subsection{Hazır Giyim Mağazacılık Sektörü}

Giyim, insanların en önemli gereksinimlerinden biridir ve bu gereksinim tarihin ilk zamanlarında soğuk hava gibi tabiatın olumsuz etkilerinden korunmak amacıyla insanların örtünmesiyle başlamıştır [14]. Mamul kumaş ve aksesuarlarla beraber insanların standartlaştırılmış ölçülerine göre belli üretim teknik ve prosesleri kullanılarak yapılan giyim eşyalarına hazır giyim denir. Bu sektör dokuma ya da örme kumaşlardan kadın, erkek ve çocuklar için yaşamlarının her alanında kullanabilecekleri giyilmek üzere üretilmiş tüm iç ve dış giysileri içermektedir [15]. Hazır giyim sektörü, kumaşın giyim eşyasına dönüşme sürecinden, giysilerin dağıtım ve satış sürecine kadar insan gücünün çok fazla kullanıldığı, emek yoğun bir sektördür [16].

Hazır giyim, dünya çapında olduğu gibi Türkiye'de de çok büyük istihdam ve ekonomik gelir sağlayan bir sektör haline gelmiştir. Türkiye ihracatının yaklaşık üçte birini kapsayan hazır giyim iş kolu, ülkeye sağladığı ekonomik gelirin yanı sıra istihdam için de çok önemli rol oynayarak, Türkiye'deki toplam istihdamın \%20'sini oluşturmaktadır. Sektörün en önemli hammaddesi olan pamuk üretiminde Türkiye'nin dünya sıralamasında 6. olması da sektörün ülkemizdeki boyutu, istihdam kapasitesi, teknoloji düzeyi ve sosyal etkileşimini olumlu yönde etkilemektedir. Sektörün mevcut konumunun önümüzdeki yıllarda korunması ve hatta daha da geliştirilmesi ve yükselmesi beklenmektedir [17].

\subsubsection{Hazır Giyim Mağazacılık Sektöründe İş Sağllğı ve Güvenliğini Tehdit Eden Faktörler}

Çalışma hayatı insanların hayatının büyük bir kısmını oluşturmaktadır. Çalışma ortamında oluşan fiziksel, biyolojik, kimyasal, ergonomik, psikososyal vb. tehditler karşısında önlem alınmadığ 1 takdirde çalışanların tam iyilik halleri olumsuz etkilenebilmektedir [18]. Mağazacılık sektöründe iş sağllğ 1 ve güvenliğini tehdit eden faktörler incelendiğinde; fiziksel, ergonomik ve psikososyal risk etmenleri başlıkları altında incelenebilir.

\section{Fiziksel Risk Etmenleri}

Fiziksel risk etmenlerinden gürültü, özellikle tekstil-hazır giyim, metal, dökümhaneler, kimya ve otomotiv yan sanayi sektörleri gürültü kaynağı olarak ön plana çıkmaktadır [19]. Hazır giyim mağazalarında, müşteriye mağazayı cazip göstermek amaçlı çok yüksek seslerde müzik yayını yapmak, çalışanların gürültüye maruz kalmasına sebep olmaktadır.

Hazır giyim sektöründe mağazalarda, müşterinin ürünleri rahatlıkla inceleyebilmesi için optimal bir aydınlatmaya ihtiyaç vardır [20]. Uygun aydınlatma, hem iş kazalarını önlemek açısından hem de gözün korunması bakımından oldukça önemlidir. Bunun yanı sıra, çalışan üzerinde iyi hissetme, moral yüksekliği ve yorgunluk hissetmeme gibi etkileri de vardir [21].

Çalışma ortamında insanların daha rahat ve verimli çal1şabilmeleri için çalışma alanındaki hava kalitesi de oldukça önemlidir. Bu sebeple insanların hayatlarının önemli bir kısmını geçirdiği çalışma alanında termal konforu sağlamak iş güvenliğinin önceliklerindendir. Termal konfor sağlanırken; ortamın sıcaklığı, radyan 1sısı, nem durumu, hava akım hızı, yapılan işin niteliği, çalışma ortamında çalışanların giydiği iş kıyafetleri, yaş ortalaması ve cinsiyet, beslenme şekilleri, fiziki durumları ve sağlık durumları göz önünde bulundurulmalıdır.

\section{Ergonomi}

Hazır giyim mağazacılık sektöründe çalışanların yaşadığı en önemli ergonomik sorunlar; çalışma ortamlarındaki ekipman ve teçhizatların fizyolojilerine uygun olmayışı ve mağazalarda fazla ürün sergilemek adına çalı̧̧anlara yetersiz kullanım alanı bırakılmasıdır. Bu sebepten çalışanların yaşadığı kas, iskelet sistemi rahatsızlıkları en şikayetçi oldukları konudur. Bel ve boyun fitıkları, sırt ve omuzlarda ağrı, boyun düzleşmesi, ayak ve bacaklarda ağrı, kollarda uyuşma ve ağrı ve bunların yanı sıra görme problemleri ve varis çalışanların yaşadığı sağlık sorunları arasındadır [20].

\section{Psikososyal Risk Etmenleri}

Stresli çalışma, trafik, vardiyalı çalışma sistemi, uyku bozukluğu gibi durumlar çalışanların iş kazalarına sebebiyet veren psikososyal risk etmenleridir. Günümüzde yeni yeni kullanılan ve detaylandırılan bu risk faktörlerinden en önemlisi strestir. İş hayatındaki stres kaynakları incelendiğinde aşırı iş yükü, görev tanımının belirsizliği, başka kişilerin sorumluluğunu üstlenmek, çalışanlarda ortaya çıkan görev çatışması, iş ile ilgili karar verme sürecine katılım, iş doyumunda yaşanan eksiklikler, gelecekle ilgili yaşanan kaygılar, işin gerekliliğine inanmama, kariyer engelleri, zamanın yapılan işe yeterli gelmemesi, iş konusunda kaygılanma, memnun olmadığı halde işyerinden ayrılamama, yönetim tarzının yanlış olması, işyerindeki üst yöneticilerle ve çalışma arkadaşlarıyla iletişim bozukluğu, çalışılan ortamın fiziki şartlarının yeterli olmaması gibi sebepler ortaya çıkmaktadır [22].

Hazır giyim mağazacılık sektörü, işin şekli ya da içeriği gereği zaman odaklı çalışılan, işin yoğun olduğu, vardiyalı çalışmanın çok fazla olduğu, psikososyal risk etmenleri ile çok fazla karşılaşılan bir sektördür. Strese neden olan 
faktörler çalışanların hem iş hayatında hem de sosyal yaşantılarında psikolojik problemler yaratmakta, iş verimini düşürmekte ve iş kazalarına sebebiyet vermektedir.

\subsection{Türkiye'de Hazır Giyim Mağazacıllk Sektöründe Yaşanan İş Kazaları İstatistikleri}

Hazır giyim iş kolunda da diğer iş kollarında da olduğu gibi çalışanların karşılaştığı fiziksel, psikososyal, ergonomik risk etmenleri gibi sebeplerden dolayı iş kazaları çok fazla yaşanmaktadır.

Hazır giyim ve tekstil sektöründe üretim ve satış alanlarında SGK 2014 verilerine göre, erkeklerin yaşadığı iş kazalarının sayısının kadınların yaşadıklarının iki katından daha fazla olduğu anlaşılmaktadır. Bu kazaların çoğu tekstil ürünleri imalatı iş kolunda yaşanmış olup, bu alanda erkek istihdamının fazla olması da iş kazası geçiren erkeklerin sayısının fazla olmasını açıklamaktadır. Sektörde kadın ve erkeklerin yaşadığı toplam kaza sayısına bakıldığında 15457 adet iş kazası ile Türkiye'deki iş kazalarının \%7'sinin bu iş kolunda yaşandığı ortaya çıkmaktadır. 2014 yılında hazır giyim ve tekstil sanayi kolunda yaşanan 10 adet meslek hastalığ da Türkiye genelinin \% 4,9'unu kapsamaktadır.

SGK verilerine bakıldığında, ölümle sonuçlanan iş kazalarında erkeklerin ölüm sayısının 20, kadınların ise 2 olduğu tespit edilmiştir. Hazır giyim ve tekstil iş kolunda 2014 yılı içerisinde yaşanan 22 ölümlü iş kazası Türkiye'deki ölümlü iş kazalarının \%1,35'ini kapsamaktadır. Meslek hastalıklarına bakıldığında ise, 2014 yılı içerisinde ölümle sonuçlanan meslek hastalığ yaşanmamıştır [13].

Yapılan çalışmalar incelendiğinde iş sağlığı ve güvenliğinin önemi ve ilkeleri ile ilgili çok farklı çalışmaların yürütüldüğü belirlenmiştir. Bunlardan, H.Akıllı ve Ö.Aydoğdu (2012) tarafından yapılan "İş Sağlı̆̆ 1 ve Güvenliğinin Önemi” isimli çalışmada [23] iş sağllğ̆ ve güvenliğinin önemi, Türkiye'de ve dünyada yaşanan iş kazalarının sayıları, 6331 sayılı kanunun ülkemize getirdikleri, kazaların nedeni, kazalardan doğan kayıplar, kazaları önleme yöntemleri hakkında bilgi vermiştir. A.Algün (2014) tarafından hazırlanan “İş Sağllğ̆ ve Güvenliğinin Temel Prensipleri” isimli çalışmada [24] ise iş sağlığı ve güvenliğinin 10 temel ilkesi ve prensipleri ile ilgili detaylı bilgiler verilmiştir.

Literatürde kaza sebeplerini incelemeye yönelik çalışmalardan, E.N.Dizdar (2001) tarafindan hazırlanan "Kaza Sebeplendirme Yaklaşımları" isimli araştırmada kaza sebeplendirme yaklaşımları, kaza teorileri, kazaya sebep olan insan hataları hakkında bilgi vermiştir [25]. A.Milli (2015) tarafindan hazırlanan "Bir Hazır Giyim İşletmesinde İş Sağlığı ve Güvenliği Kapsamında Hata Türü ve Etkileri Analizi” isimli yüksek lisans tez çalışmasında ise hazır giyim sanayi de yaşanan iş kazaları, kaza teorileri hakkında detaylı bilgi verilmiş ve hata türü ve etkileri analiz yöntemi detaylandırılmıştır [26].

$\mathrm{Bu}$ çalışmanın amacı, ülkemiz ekonomisinde önemli bir yere sahip olan hazır giyim mağazacılık sektöründe çalışanların ve bu sektörün sürükleyici faktörü müşterilerin karşı karşıya kaldığı kazaları saptamak ve bu kazaların minimize edilmesine yönelik tedbirlerin tespit edilmesine katkı sağlamaktır. Yapılan çalışmada; ülkemizde önde gelen, hazır giyim sektöründe mağazalar zincirine sahip firmada yaşanan iş kazaları, kaza nedenleri ve kaza sonucu oluşan kayıplar açısından detaylı olarak incelenmiştir. Kazaların sebepleri incelenirken güvensiz durum/güvensiz davranışlar, iş kazalarının sınıfları, mağaza içerisinde iş kazası yaşanan yerler, kaza geçirenin cinsiyeti, kaza geçiren çalışan grubu ve yıllara göre yaşanan kazaların sayısı analiz edilerek, aynı kazaların bir daha yaşanmaması için alınması gereken önlemler hakkında değerlendirme yapılmıştır. Ayrıca, çalışma kapsamında ki-kare istatistik yöntemi kullanılarak kazazedelerin görev tanımlarına göre cinsiyetlerinin dağılımını ve kazazedelerin yaralanan uzuvlarına göre yaralanma şekillerini belirlemek ve çıkan sonuçlara göre iş kazalarının yaşanmaması için alınması gereken önlemlerin tespit edilmesi amaçlanmıştır.

\section{YÖNTEM}

Bu çalışmada, hazır giyim sektöründe mağazalar zincirine sahip bir firmanın 1 Ocak 2012 tarihi ile 1 Haziran 2016 tarihi aralığında yaşadığı iş kazalarının değerlendirmesi yapılmıştır. 150 'den fazla yurt dışı mağazası, 250'den fazla Türkiye içerisinde mağazası olan bu firmanın on bine yakın çalışanı vardır. İş kazalarının değerlendirilmesinde Türkiye içerisindeki mağazalarında yaşanan 285 adet iş kazası ele alınmıştır ve kaza sayıları " $n$ " ile ifade edilmiştir. Bu kazalar değerlendirilirken, ilgili firmanın İnsan Kaynakları Departmanı tarafindan Sosyal Sigorta İşlemleri Yönetmeliği'ne istinaden Sosyal Güvenlik Kurumu'na yaptığı iş kazası bildirimleri göz önünde bulundurulmuştur. Ayrıca müşterilerin yaşadığ 1 kazalar da değerlendirmeye alınmış ve bu değerlendirmeler yapılırken, mağaza müdürlerinin İnsan Kaynakları Departmanı'na gönderdikleri mail içerikleri incelenmiştir. Sosyal Güvenlik Kurumu'na yapılan bildirimlerde kullanılan İş Kazası Bildirim Formu; kazazedenin cinsiyeti, firma içerisindeki görev tanımı, kazanın yaşandığı tarih, kaza sonucu yaşanan iş gücü kaybının kaç gün olduğu, kazazedede meydana gelen zararın fiziksel olarak tanımı bilgilerini içermektedir. Yapılan çalışmada, İş Kazası Bildirim Formu'nda bildirimi yapılan bilgiler doküman üzerinde değerlendirilmiş, kazaların sebepleri tehlikeli durum/tehlikeli davranış olarak incelenmiş ve kaza sınıfları tespit edilmiştir. 
Çalışmada, kazalar değerlendirilirken çalışanın görevi, cinsiyeti, kaza yaşanan yıl, kaza yaşanan yer, kaza sınıfi, kaza oluş şekli, tehlikeli durum/davranış koşulları, yaralanma şekli ve yaralanan uzuv dikkate alınmıştır. Bu etmenler aşağıda belirtilen kriterler dahilinde değerlendirmeye alınmıştır.

Görev tanımına göre yaşanan kazaların sıklığını değerlendirmek için, kaza geçiren personellerin firma tarafından tebliğ edilen görev tanımları dikkate alınmıştır. Görev tanımları mağaza çalışanı, depo çalışanı, yönetici, müşteri ve diğer kategorileri altında değerlendirmeye alınmıştır. Diğer olarak tanımlanan kategoride kaza sayısı az olan görev tanımları değerlendirilmiştir.

Kazazedelerin cinsiyetleri değerlendirilirken kadın, erkek olarak değerlendirilmiş, kaza raporunda kazazedenin cinsiyetinin belirtilmediği durumlar için ise "Uygulanabilir Değil" anlamında "NA" ifadesi kullanılmıştır.

Kazanın gerçekleştiği yer analiz edilirken mağaza kullanım alanı spesifik bölümlere ayrılmadığı için aşağıdaki başlıklar şeklinde bir sınıflandırma yapılmıştır:

Mağaza İçi: Mağaza içerisinde yaşanan kazalar

Depo: Mağazanın depo alanında yaşanan kazalar

Ofis: Mağazanın ve genel müdürlüğün ofis alanlarında yaşanan kazalar

Mağaza Dışı: Lavabolar, dinlenme alanları, araç içi, gibi alanlar

Diğer: Kaza raporunda ya da tutanaklarda kazanın gerçekleştiği yer belirtilmediği durumlar

Kaza sınıfları değerlendirilirken bilimsel açıklamalara bağlı olarak kaza sonucunda 3 güne kadar istirahat alan kazazedelerin yaşadığı kazalar minör, 3 gün ve üzerinde istirahat alan kazazedelerin geçirdiği kazalar major, hiç kimsenin zarar görmediği ancak maddi hasarın oluştuğu kazalar maddi hasar olarak değerlendirilmiştir.

Heinrich'in kaza zincirinde 3. sırada olan tehlikeli durum ve davranışlar kazanın asıl sebebini tespit etmek için çok önemlidir. Bu çalışmada tehlikeli durum ve tehlikeli davranışlar değerlendirilirken yapılan bilimsel açıklamalar dikkate alınmıştır. Diğer başlığı altında ise kaza raporlarında kazanın detayı belirtilmemiş olan kazalar ve genel hastalık halleri dikkate alınmıştır.

Kazanın insana verdiği zarar yaşanan olayın boyutlarını belirlemede çok önemli bir rol oynamaktadır. Bu sebepten yaralanma şekilleri analiz edilmiş ve hekim tarafindan düzenlenen raporda konulan tanılar dikkate alınmıştır. Yaralanma şekilleri burkulma/incinme, kesik, kırık/çıkık/çatlak, sıyrık, yumuşak doku zedelenmesi gibi başlıklarda değerlendirilmiş olup, kaza sonucu herhangi bir yaralanma yaşanmadıysa yaralanma yok kapsamında dikkate alınmıştır. Diğer başlığı altında ise daha düşük oranda yaşanan genel hastalık, ezilme ve kas yırtılması vakaları incelenmiştir.

Kaza sonucunda insanların en çok hangi uzuvlarının zarar gördüğ̈̈nü tespit etmek alınması gereken önlemleri belirlemede oldukça etkilidir. Yaralanan uzuvlar kategorilendirilirken ayak ve bacak bölgesi; ayak, ayak parmakları ve bacak bölgesini, baş bölgesi; ağız, diş, burun, göz, yüz ve baş kısımlarını kapsamaktadır. El ve kol bölgesi olarak belirlenen kategori; omuz, kol, el ve el parmaklarını kapsamaktadır. Gövde bölgesi ise bel, sırt, kalça, omurga ve iç organları kapsamaktadır. Diğer olarak tanımlanan kısımda kaza raporunda vücudun hangi kısmında yaralanma olduğu belirtilmeyen kısımlar için kullanılmıştır.

Araştırmalarda elde edilen sonuçları değerlendirmek için, ham verileri düzenlemek, özetlemek ve özelliklerini belirlemek gerekmektedir. Elde edilen veriler kategorilere ayrılır ve her kategoriye ait değerlendirmeye sınıf frekans1 denir ve tespit edilen frekanslar tablolar halinde gösterilir [27]. Çalışmada kullanılan ki-kare testi çoğunlukla iki ya da daha çok grup arasında fark olup olmadığını, iki değişken arasında bağ olup olmadığını, gruplar arası homojenlik olup olmadığını, örneklerden elde edilen verilerin homojen dağılımını test eden bir yöntemdir [28].

$\mathrm{Bu}$ çalışmada, iş kazalarının yıllara, çalışan grubuna, cinsiyete, iş kazası yaşanan yerin bölgesine, kaza sınıfına ve kazaya sebep olan tehlikeli durum ve tehlikeli davranışlara göre dağılımı değerlendirilmiştir. Ayrıca, görev tanımı ile kazazedenin cinsiyeti arasında homojen bir dağılım olup olmadığını test etmek için ki-kare istatistik yöntemi kullanılmıştır. Bu yöntem aynı zamanda yaralanan uzuv ile yaralanma şekilleri arasında bağ olup olmadığını ve bu değişkenlerin arasında homojen bir dağılım olup olmadığını test etmek için de kullanılmıştır. Ki-kare istatistik yöntemi kullanılarak; kazazedelerin cinsiyetleri ile görev tanımları ve yaralanan uzuv ile yaralanma şekilleri arasındaki dağılımların belirlenmesi hedeflenmiştir. Yapılan bu değerlendirmelerle amaçlanan; yaşanan iş kazalarının kök nedenlerini tespit etmek, çözüm önerileri getirmek ve aynı tür kazaların bir daha yaşanmaması sağlamaktır. Ki-kare yöntemi uygulanırken "Statistical Package for the Social Sciences" (SPSS) programı kullanılmıştır. Değerlendirmeye alınan 285 adet iş kazası verilerinin tamamı uygun bulunmuş ve her kriter kodlanarak SPSS paket programına veri girişleri yapılmıştır.

\section{SONUÇLAR}

$\mathrm{Bu}$ çalışmada, yaşanan iş kazaları yıllara göre değerlendirilmiştir ve en çok iş kazasının 2015 yllında \%38.6'l1k bir oranla yaşandığ 1 gözükmektedir. 2016 yılında yaşanan 
kazalar 1 Haziran tarihine kadar değerlendirildiği için, 2015 ve 2016 yılında yaşanan iş kazaları sayısının diğer yıllara göre daha fazla olduğu tespit edilmiştir (Tablo 3.1).

Tablo 3.1 Yıllara göre yaşanan iş kazalarının dağılımı

\begin{tabular}{|l|c|c|}
\hline Kaza Yll & $\mathbf{n}$ & $\mathbf{\%}$ \\
\hline $\mathbf{2 0 1 2}$ (1 Ocak itibari ile) & 22 & 7.7 \\
\hline $\mathbf{2 0 1 3}$ & 58 & 20.4 \\
\hline $\mathbf{2 0 1 4}$ & 43 & 15.1 \\
\hline $\mathbf{2 0 1 5}$ & 110 & 38.6 \\
\hline $\mathbf{2 0 1 6}$ (Haziran ayına kadar) & 52 & 18.2 \\
\hline Toplam & 285 & 100 \\
\hline
\end{tabular}

Çalışan grubuna göre yaşanan iş kazalarınının frekansları değerlendirildiğinde, kaza geçirenlerden mağaza içerisinde görevli çalışanların \%61.8'lik oranla en çok iş kazası geçiren grup olduğu tespit edilmiştir. Mağazaya müşteri olarak gelen kişilerin yaşadığı kazalar ise \% 14'lük bir orana sahiptir (Tablo 3.2).

Tablo 3.2 Çalışan grubuna göre iş kazalarının dağılımı

\begin{tabular}{|l|c|c|}
\hline Kaza Geçiren Çalışan Grubu & $\mathbf{n}$ & $\mathbf{\%}$ \\
\hline Mağaza Çalışanı & 176 & 61.8 \\
\hline Depo Çalışanı & 25 & 8.8 \\
\hline Yönetici & 11 & 3.9 \\
\hline Müşteri & 40 & 14 \\
\hline Diğer & 33 & 11.6 \\
\hline Toplam & 285 & 100 \\
\hline
\end{tabular}

İş kazası geçiren kişilerin cinsiyetleri değerlendirilirken mağaza çalışanları ve müşterilerin yaşadığı kazaların tümü dikkate alınmıştır. Tablo 3.3'te görüldüğ ü gibi iş kazalarını $\% 50.5$ oranla kadınların, $\% 43.9$ oranla erkeklerin yaşadığ 1 ortaya çıkmaktadır. Müşterilerin yaşadığı kazalarda mağaza müdürleri tarafından İnsan Kaynakları Departmanı'na gönderilen bilgilendirme mailleri incelenmiştir.

Tablo 3.3 Cinsiyete göre yaşanan iş kazalarının dağılımı

\begin{tabular}{|l|c|c|}
\hline Kaza Geçirenin Cinsiyeti & $\mathbf{n}$ & $\mathbf{\%}$ \\
\hline Kadın & 144 & 50.5 \\
\hline Erkek & 125 & 43.9 \\
\hline NA & 16 & 5.6 \\
\hline Toplam & 285 & 100 \\
\hline
\end{tabular}

Kaza yaşanan yerler detaylandırıldığında en çok iş kazası $\% 75.1$ 'lik oranla mağaza içerisinde yaşanmıştır. Firma yetkililerinden alınan bilgi doğrultusunda mağazaların depo alanları mağazaların ortalama \%10'unu kapsamaktadır ve depo alanlarında yaşanan iş kazalarının oranı \%14.4 olarak tespit edilmiştir (Tablo 3.4).

Tablo 3.4 Yaşanan iş kazalarının kaza yerlerine göre dağılımı

\begin{tabular}{|l|c|c|}
\hline Kaza Yeri & $\mathbf{n}$ & $\mathbf{\%}$ \\
\hline Mağaza içi & 214 & 75.1 \\
\hline Depo Alanı & 41 & 14.4 \\
\hline Ofis & 11 & 3.9 \\
\hline Mağaza Dışı & 14 & 4.9 \\
\hline Diğer & 5 & 1.8 \\
\hline Toplam & 285 & 100 \\
\hline
\end{tabular}

Kazaların sınıflarına göre yaşanan kazaların dağılımı değerlendirilmiştir (Tablo 3.5). Kaza sınıfları belirlenirken bilimsel açıklamalar göz önünde bulundurulmuştur [11]. İş günü kaybı 3 güne kadar olan, küçük hasarlı ve çoğunlukla ilk yardım gerektiren minör kazalar değerlendirilmiş ve \%77.9'luk oranla daha fazla yaşandığı tespit edilmiştir. İş Sağlığı ve Güvenliğine İlişkin İşyeri Tehlike Sınıfları Tebliği EK-1'e istinaden Hazır Giyim Mağazacılık iş kolu az tehlikeli sınıfta yer almaktadır [29].

Tablo 3.5 Kaza sınıfına göre yaşanan kazaların dağılımı

\begin{tabular}{|l|c|c|}
\hline Kaza Sınıfı & $\mathbf{n}$ & $\mathbf{\%}$ \\
\hline Major & 61 & 21.4 \\
\hline Minor & 222 & 77.9 \\
\hline Maddi Hasarlı & 2 & 0.7 \\
\hline Toplam & 285 & 100 \\
\hline
\end{tabular}

Heinrich, iş güvenliği çalışmalarında 10 temel ilkeden bahsetmiştir. Bu ilkelerin ikincisinde iş kazalarının \%88'inin tehlikeli davranışlardan, \%10'unun tehlikeli durumlardan, $\% 2$ 'sinin ise nedeni bilinmeyen durumlardan oluştuğunu ifade etmiştir [3]. Tablo 3.6 incelendiğinde çalışma yapılan firmada yaşanan iş kazalarının \%68.1'inin tehlikeli davranışlardan kaynaklandığı ortaya çıkmaktadır. Tehlikeli durumlardan kaynaklanan iş kazalarının oranı ise \%11.6 olarak tespit edilmiştir.

Tablo 3.6 Tehlikeli durum ve tehlikeli davranışların yaşanan iş kazalarına göre dağılımı

\begin{tabular}{|l|c|c|}
\hline Tehlikeli Durum \& Tehlikeli Davranış & n & \% \\
\hline Tehlikeli Davranış & 194 & 68.1 \\
\hline Tehlikeli Durum & 33 & 11.6 \\
\hline Tehlikeli Durum+Tehlikeli Davranış & 23 & 8.1 \\
\hline Diğer & 35 & 12.3 \\
\hline Toplam & 285 & 100 \\
\hline
\end{tabular}


Tablo 3.7 Görev tanımına göre kazazedelerin cinsiyetlerinin dağılımlarının değerlendirilmesi

\begin{tabular}{|c|c|c|c|c|c|c|c|c|}
\hline & & & Mağaza Çalışanı & Depo Çalışanı & Yönetici & Müşteri & Diğger & \\
\hline \multirow{6}{*}{ 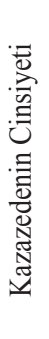 } & \multirow{2}{*}{ 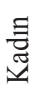 } & $\mathrm{n}$ & 114 & 0 & 3 & 14 & 13 & \multirow{8}{*}{0.001} \\
\hline & & $\%$ & 64.8 & 0.0 & 27.3 & 35 & 39.4 & \\
\hline & \multirow{2}{*}{$\begin{array}{l}\frac{y}{d} \\
\frac{y}{ \pm} \\
\text { th }\end{array}$} & $\mathrm{n}$ & 60 & 25 & 8 & 13 & 19 & \\
\hline & & $\%$ & 34.1 & 100 & 72.7 & 32.5 & 57.6 & \\
\hline & \multirow{2}{*}{$\overleftrightarrow{Z}$} & $\mathrm{n}$ & 2 & 0 & 0 & 13 & 1 & \\
\hline & & $\%$ & 1.1 & 0.0 & 0.0 & 32.5 & 3.0 & \\
\hline \multirow{2}{*}{\multicolumn{2}{|c|}{ Toplam }} & $\mathrm{n}$ & 176 & 25 & 11 & 40 & 33 & \\
\hline & & $\%$ & 100 & 100 & 100 & 100 & 100 & \\
\hline
\end{tabular}

Ki-kare yöntemi ile yapılan çalı̧̧mada, kazazedelerin görev tanımlarına göre cinsiyetleri arasında istatistiksel olarak anlamlı farklılık bulunmaktadır. Tablo 3.7'ye göre mağaza çalışanı kazazedelerden kadınların oranı (\%64.8), erkeklerin oranından (\%34.1) anlamlı şekilde yüksek çıkmıştır. Depo çalışanlarında bütün kazalar erkekler tarafından yaşanmıştır. Yönetici kademesinde çalışanlarının \%81'i erkek olan ilgili firmada, yönetici statüsündeki kazazede erkeklerin oranı (\%72.7), kadınların oranından (\%27.3) fazla çıkmıştır. Müşterilerin yaşadığ 1 kazalar değerlendirildiğinde ise erkek ve kadınların eşit sayılarda kazalar yaşadığı anlaşılmaktadır. Sonuç olarak, en fazla kaza geçiren grup mağaza çalışanı kadınlar olarak tespit edilmiştir.
Kazazedelerin yaralanan uzuvlarına göre yaralanma şekilleri dağılımları da ki-kare yöntemi ile değerlendirilmiş, p değeri 0.001 olarak bulunmuş ve aralarında istatistiksel olarak anlamlı farklılıklar tespit edilmiştir. Tablo 3.8'e göre ayak ve bacak bölgesinde yaşanan yaralanma şekillerinden burkulma/incinme (\%38.0), yumuşak doku zedelenmesinden (\%28.0), kırık/çıkık/çatlak ile sonuçlanan kazalardan (\%10) anlamlı şekilde yüksektir. Baş bölgesinde olan yaralanma şekillerine bakıldığında en çok yumuşak doku zedelenmesi (\%61.5) ile sonuçlanan kazaların yaşandığı ortaya çıkmaktadır. El ve kol bölgesindeki yaralanma şekillerinden kesik (\%35.2) ve burkulma/incinme (\% 18.3) sonucu yaşanan kazaların daha fazla yaşandığ 1 tespit edilmiştir. Gövde

Tablo 3.8 Yaralanan uzuva göre yaralanma şekillerinin dağılımlarının değerlendirilmesi

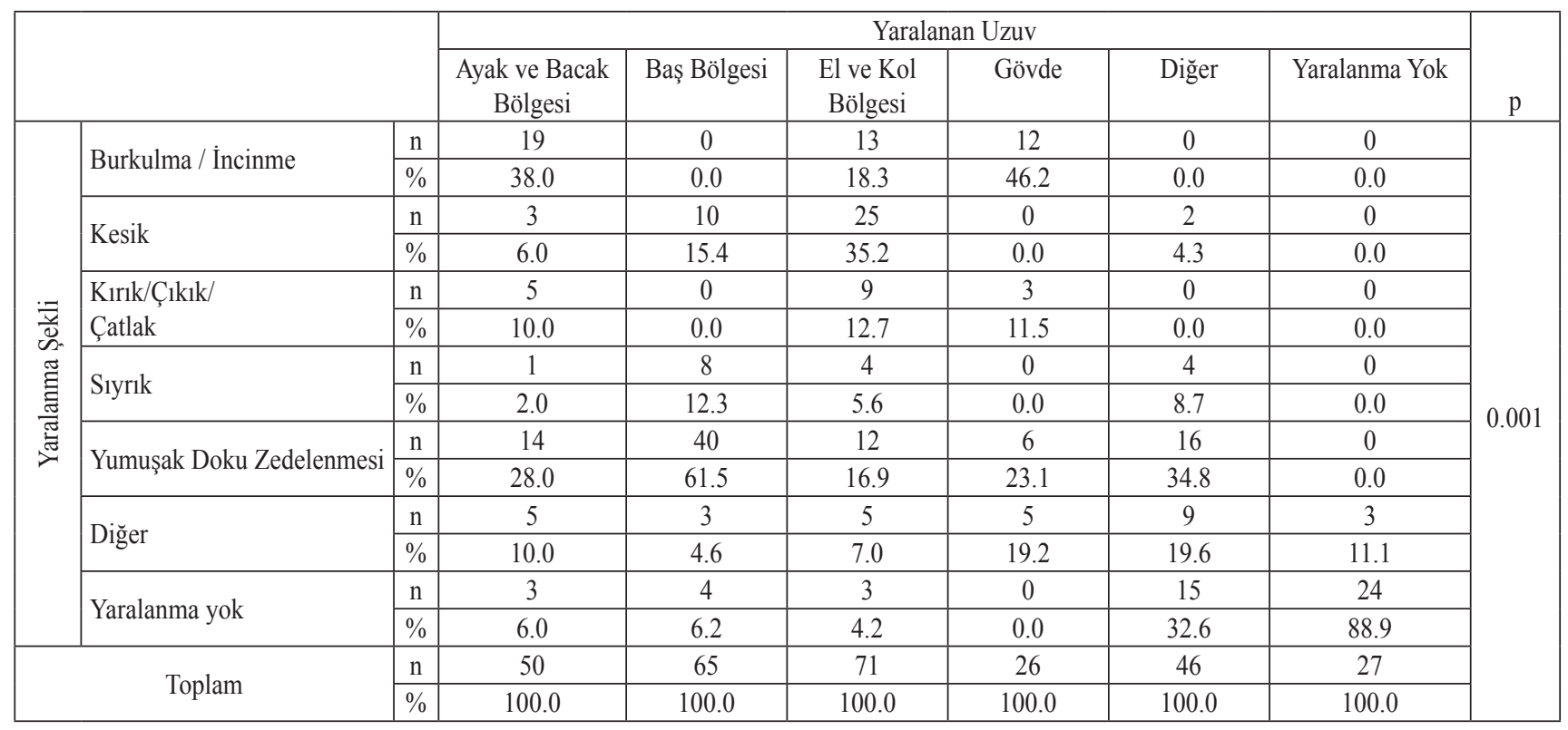


bölgesinde yaşanan yaralanma şekillerine bakıldı̆̆ında ise, burkulma/incinme (\% 46.2) vakasının daha çok yaşandığı gözükmektedir.

Sonuç olarak, en çok baş bölgesinde yumuşak doku zedelenmesi (\%61.5) yaşandığı ortaya çıkmaktadır. Firmanın yaptığı bildirim formlarında verilen bilgilere göre, baş bölgesi yaralanması olan kazalar reyon bölgesinde düzenleme yapan personellerin kafasını rafa ya da standa çarpması sonucu yaşadığ 1 yaralanmalar ortaya çıkmaktadır.

Bel ağrılarını kapsayan kas iskelet sistemi rahatsızlıkları ergonomik alanında yapılan araştırmaların büyük bir kısmını oluşturmaktadır. Yapılan çalışmalar bel ağrıları ile yapılan iş arasında ilişki olduğunu göstermektedir [30]. Elle Taşıma İşleri Yönetmeliği'nde elle taşıma işleri ile ilgili risk faktörleri yükün özellikleri, fiziksel güç gereksinimi, çalışma ortamının özellikleri ve yapılan işin gerekleri olarak belirtilmiştir [31]. Kazazedelerin gövde bölgesindeki burkulma ve incinme oranı \% 46.2 olarak çıkmış ve gövde bölgesindeki incinmeler bel incinmesi olarak yaşanmıştır (Tablo 3.8).

\section{DEĞERLENDİRME}

Hazır giyim mağazacılık sektöründe mağazalar zinciri olan firmada yaşanan iş kazalarının araştırılması sonucu ortaya çıkan en önemli sonuçlar ve öneriler aşağıdaki gibi sıralanabilir.

Yaşanan kazaların yıllara göre dağılımları incelendiğinde iş kazalarının en çok 2015 yılında \%38.6' lık bir oranla yaşandığı gözükmektedir. İlgili firmanın kazaları 1 Haziran 2016 tarihine kadar değerlendirilmiştir ve ilk 5 ayda yaşanan iş kazalarının oranı da (\%18.2) diğer yıllara göre yüksek çıkmıştır. 6331 Sayılı Kanun'un getirisi olan iş sağlığ ve güvenliği profesyonellerinden hizmet alma zorunluluğu ile beraber iş kazası sayılarında artış yaşandığı ortaya çıkmaktadır. İş güvenliği uzmanı ve işyeri hekimi hizmeti ile iş kazalarının doğru tespit edildiği ve bildirim sayılarında artış yaşandığ tespit edilmiştir.

Yaşanan kazaların sebepleri incelendiğinde tehlikeli davranış oranı $\% 68.1$ ve tehlikeli durum oranı $\% 11.6$ olarak tespit edilmiştir. Tehlikeli davranış oranının yüksek çıkması ve minör boyutta yaşanan kazaların oranının (\%77.9) daha yüksek çıkması kazaların büyük bir oranının kolaylıkla önlenebilir olduğunu göstermektedir. Çalışanların iş güvenliği eğitimleri ve seminerleri ile güvenli çalışma koşulları konusunda bilgilendirilmesi yaşanan kazaların azalacağını göstermektedir.

Kaza yaşanan yerler incelendiğinde $\% 75.1$ oranında mağaza içerisinde kazaların yaşandığ 1 ve mağaza içerisinde yaşanan kazaların büyük bir oranının yüksekten düşme, çarpma sonucu yaşandığı ortaya çıkmıştır. Çalışanların yüksekten ya da basamaktan düşme sonucu yaşadığı kazalar detaylandırıldığında çalışanların uygun merdiven kullanarak yüksek yerlere erişimlerini sağlamadığı, iş yoğunluğu sebebiyle vakit kaybetmemek için tabure, sandalye ya da raf kenarına basarak yükseğe erişim sağlamaya çalıştığı tespit edilmiştir. Uygun merdiven kullanımı ile ilgili çalışanlara eğitim verilmesi ve çeşitli görsellerle bu eğitimlerin desteklenmesi ile yaşanan bu kazaların önüne geçilmesi sağlanabileceltir. Mağazaların tasarımı yapılırken, mağaza kullanım alanına göre eşyaların yerleşimi ve çalışan sayısının belirlenmesi, kullanım alanını arttıracak ve alan darlığından dolayı çarpma sonucu yaşanan kazaların önlenmesi sağlanabilecektir. Mağaza içerisinde mevcut alana maksimum ürün yerleştirebilmek ve sergileyebilmek için alanların insan antropometrik yapısı gözardı edilerek tasarım yapıldığı düşünülmektedir.

Çalışanların çarpma sonucu yaşadığı kazaların önemli bir oranı çok alçak seviyelerdeki raflara eğilirken ya da dar alanlarda hareket ederken meydana geldiği saptanmıştır. Raf tasarımlarının insanların rahat kullanabileceği ergonomik şekilde tasarımlanması ve mevcut durumda kullanılan keskin köşeli mobilyalar yerine, daha yuvarlak hatlara sahip mobilyaların kullanımı çalışanların mağaza içerisinde rahat ve güvenli hareket etmesini sağlayacaktır. Müşteri potansiyeli ve çalışan sayısı göz önünde bulundurularak oluşturulan kullanım alanları çalışanların ve müşterilerin mağaza içerisinde yaşadığı kazaları azaltacaktır.

Alınan bu önlemler ile çalışanların iş verimi, performansı ve güvenliği artacak, güvensiz davranış ve güvensiz durumlar azalacak, dolayısıyla iş kazalarının engellenmesi sağlanabilecektir. Yaşanan kazalar dolaylı ve dolaysız maliyetlere sebep olurken diğer taraftan toplum vicdanında da büyük yaralar açmaktadır. İşyerinde sağlık ve güvenliğin devamlılı̆̆ını sağlayabilmek için bütün kazaların önlenebilir olduğu farkındalığı ile işveren ve çalışanlarda iş güvenliği bilincinin oluşması, iş güvenliği prensiplerinin ve ilkelerinin dikkate alınması çok önemlidir.

\section{KAYNAKÇA}

[1] Ölmez, T. (2014) Hazır Giyim İşletmelerinde İş Sağlğğ ve Güvenliği Uygulamaları. Yüksek Lisans Tezi, Gazi Üniversitesi Eğitim Bilimleri Enstitüsü, Ankara, Türkiye, 2,38,39.

[2] T.C. Bilim, Teknoloji ve Sağlık Bakanlığı Sanayi Genel Müdürlüğü (2014): Türkiye Tekstil, Hazır giyim Ve Deri Ürünleri Sektörleri Strateji Belgesi Ve Eylem Planı (2015-2018), Ankara, Türkiye.

[3] Atılgan, T., Dengizler, İ. (2007) Hazır Giyim Sektöründe Örgütsel Stres Üzerine Bir Araştırma, Dokuz Eylül Üniversitesi Sosyal Bilimler Enstitüsü Dergisi, 9, 62-93.

[4] Avc1, A. (1998) İşyerinde İşçi Sağlığı ve İş Güvenliği 
Mevzuatı, 2.Baskı, Alfa Yayıncılık, İstanbul, s:64.

[5] Yaman, M. (2004) İş Sağlığı ve Güvenliği mi? O da ne? ,1. Bask1, İsgiad Yayınları, Ankara, s:7.

[6] Yiğit, A. (2013) İş Güvenliği, 3.Baskı, Dora Yayıncılık, Bursa.

[7] Altan, Z., Gerek, N., Güven, E. (2000) İş ve Sosyal Güvenlik Hukuku, Anadolu Üniversitesi Yayınları, Eskişehir, s.190192.

[8] Sosyal Sigortalar ve Genel Sağlık Sigortası Kanunu (2006), Ankara.

[9] Cuscio, N. F. (1995) Managing Human Resources. 5. Edition, Irwin Mc Graw Hill.

[10] Seber, V. (2012) İşçi Sağlığı ve İş Güvenliğinde Risk Analizleri Nasıl Yapılır?, Elektrik Mühendisliği Dergisi, Sayı 445, s.30-34.

[11] Yılmaz, G. (2009) İş Kazalarının Nedenleri ve Maliyeti, Mühendis ve Makina Dergisi, Cilt 50, Say1 592, s.27-32.

[12] Üçüncü, K. (2015) 2014 Y1lı SGK İş Kazası İstatistiklerinin Analizi, s.1-6.

[13] T.C. Çalışma ve Sosyal Güvenlik Bakanlığg (2015) Çalışma Hayatı İstatistikleri 2014, Ankara.

[14] Şahin, A. (2009) Tüketicilerin Haute Couture ve Hazır Giyim Tercihleri İstanbul-Konya İllerinde Örnek Bir Araştırma, Yayınlanmamış Yüksek Lisans Tezi, Selçuk Üniversitesi Sosyal Bilimler Enstitüsü.Şahin, 2009: 38

[15] Orta Karadeniz Kalkınma Ajansı (2014) Tekstil ve Hazır Giyim Sektör Raporu.

[16] Uğurlu, F. (2011) Tekstil Sektöründe İş Sağlığ1 ve Güvenliği, Çalışma ve Sosyal Güvenlik Bakanlığı, İş Teftiş Kurulu Başkanlığı, Adana.

[17] T.C. Bilim, Sanayi ve Teknoloji Bakanlığı 2015-2018, Sanayi Genel Müdürlüğü, Türkiye Tekstil, Hazır Giyim ve Deri Ürünleri Sektörleri Strateji Belgesi ve Eylem Planı

[18] Çarıkcı, M. N. (2011) İş Teftişi Sistemi Bakışıyla Kobilerde Karşılaşılan Sorunlar ve Çözüm Önerileri, İş Sağlığı ve Güvenliği dergisi, 50, s.4.
[19] Gönüllü, M.T., Avşar, Y., Arslankaya, E., Tosun, İ., (2002) Değişik Endüstri Birimlerinde Oluşan Gürültülerin Araştırılması Ve İşitme Sağlığı Açısından Değerlendirilmesi

[20] Kariptaş, F.S., Yarael, B., Ünver, B., (2012) Ofis Mekanlarında Ergonominin Çalışanlar Üzerindeki Psikolik ve Psikolojik Etkileri. 18. Ulusal Ergonomi Kongresi, Gaziantep.

[21] Kürkçü, E.A., Çakar, İ., Zeyrek, S. (2013) İşyerlerinde Aydınlatma, İş Sağlığı ve Güvenliği Merkezi Müdürlüğü (İSGÜM), Ankara.

[22] Atılgan, T., Dengizler, İ. (2007) Hazır Giyim Sektöründe Örgütsel Stres Üzerine Bir Araştırma, Dokuz Eylül Üniversitesi, Sosyal Bilimler Enstitüsü Dergisi, Cilt 9, Sayı 2, İzmir.

[23] Akıllı, H., Aydoğdu, Ö. (2012) İş Sağlığı ve Güvenliğinin Önemi, Maden Tetkik ve Arama Genel Müdürlüğü, Enerji Hammadde Etüt ve Arama Dairesi Başkanlığı, Ankara, s.245250.

[24] Algün, A. (2014) İş Sağlığ1 ve Güvenliğinin Genel Prensipleri, TMMOB EMO Ankara Şubesi Haber Bülteni 2014/3,s.3.

[25] Dizdar, E.N. (2001) Kaza Sebeplendirme Yaklaşımları, Türk Tabipler Birliği Mesleki Sağlık ve Güvenlik Dergisi, Temmuz Say1s1, s.26-31.

[26] Milli, A. (2015) Bir Hazır Giyim İşletmesinde İş Sağlığı ve Güvenliği Kapsamında Hata Türü ve Etkileri Analizi (Failure Mode And Effect Analysis) Yöntemi ile Risk Analizi Yüksek Lisans Tezi, Gazi Üniversitesi Eğitim Bilimler Enstitüsü, Ankara.

[27] Spiegel, M.R., Stephens, L.J. (2004) Teori ve Problemlerle İstatistik, Çeviren: Esin, A., Çelebioğlu,S., 3. Bask1, Nobel Dağıtım, Ankara.

[28] Güngör, M., Bulut, Y. (2008) Ki-Kare Testi Üzerine, Doğu Anadolu Bölgesi Araştırmaları, Elazı̆̆.

[29] İş Sağlığı Ve Güvenliğine İlişkin İşyeri Tehlike Sınıfları Tebliği EK-1, (2016) Çalışma ve Sosyal Güvenlik Bakanlığı.

[30] Health and Safety Authority (Ireland) (2005) Guidance on the Management of Manual Handling in the Workplace, Dublin.

[31] Elle Taşıma İşleri Yönetmeliği, Resmi Gazete Sayıs1: 28712, Resmi Gazete Tarihi: 24.07.2013, T.C. Resmi Gazete, Ankara 